\title{
Pengaruh Terapi Akupresur terhadap Nyeri Punggung Bawah pada Ibu Hamil TM III di Wilayah Kerja Puskesmas Abian Semal 1
}

\author{
Ni Gusti Ayu Pramita Aswitami ${ }^{1}$, Putu Mastiningsih ${ }^{1}$ \\ ${ }^{1}$ STIKES Bina Usada Bali,Jln.Kubu Gunung Tegal Jaya Dalung \\ Email: tami_chant@yahoo.com
}

Received 10 September 2018; Accepted 10 September 2018; Published 6 November 2018

\begin{abstract}
Lower back pain is a complaint that is often experienced by pregnant women. This is caused by hormonal changes and changes in maternal posture associated with musculoskeletal. Treatment of back pain can be treated non-pharmacologically with acupressure therapy. Acupressure therapy can release muscle tension, improve blood circulation and increase the body's energy strength. The purpose of this study was to determine the effect of acupressure therapy on back pain in pregnant women TM III in the working area of Abiansemal I Community Health Center in Badung Regency. The research method used pre experiment with one group pre post test design. Subjects were third trimester pregnant women who experienced back pain as much as 20 people. This study was conducted in the working area of the Abiansemal Community Health Center I in February-June 2018. From statistical tests using Wilcoxon test showed significant results $(p<0.05)$ that acupressure therapy has an effect on lower back pain in pregnant women in Third Trimester.
\end{abstract}

Keywords: Acupressure, pregnant women

Copyright $@ 2018$ STIKes Surya Mitra Husada

All right reserved.

This is an open-acces article distributed under the terms of the Creative Commons AttributionShareAlike 4.0 International License.

\section{PENDAHULUAN}

Secara normal ibu hamil akan mengalami perubahan baik secara fisik maupun psikologi. Pada masa kehamilan seiring dengan membesarnya uterus, maka pusat gravitasi akan berpindah kearah depan sehingga ibu hamil harus menyesuaikan posisi berdirinya, dimana ibu hamil harus bergantung dengan kekuatan otot, penambahan berat badan, sifat relaksasi sendi, kelelahan serta postur sebelum hamil. Postur tubuh yang tidak tepat akan memaksa peregangan tambahan dan kelelahan pada tubuh, terutama pada bagian punggung bawah sehingga akan menyebabkan terjadinya sakit atau nyeri pada bagian punggung bawah ibu (Husin,2014).

Nyeri merupakan suatu kondisi subjektif yang tidak menyenangkan yang meliputi pengalaman sensorik maupun emosional. Nyeri punggung bawah pada kehamilan menjadi masalah yang mengganggu kenyamanan ibu saat menjalani proses kehamilan (Stewart,2011). Terdapat lebih dari 50\% perempuan di Amerika Serikat, Kanada, Iceland, Turki, Korean dan Israel menderita keluhan nyeri punggung bawah saat kehamilan, hal ini menyebabkan terganggunya rutinitas seharihari dan mempengaruhi kualitas hidup mereka (Katonis, 2011). Prognosis nyeri punggung bawah akan buruk apabila tidak ditangani dengan baik. Ibu hamil yang mengalami nyeri punggung bawah 
akan kesulitan untuk berdiri, duduk bahkan berpindah dari tempat tidur. Dampak buruknya adalah kesulitan untuk berjalan apabila nyeri telah menyebar ke area pelvis dan lumbar (Association of Chartered Physiotherapists In Woman Health, 2011).

Menurut beberapa penelitian berbagai macam teknik komplementer yang dapat diterapkan untuk mengatasi nyeri punggung bawah pada kehamilan yang telah dikembangkan antara lain terapi pijat $(61,4 \%)$, relaksasi $(42,6 \%)$, yoga $(40,6 \%)$ dan akupresur $(44,6 \%)$ (Wang dkk, 2005). Akupresur adalah salah satu bentuk fisioterapi dengan memberikan pemijatan dan stimulasi pada titik-titk tertentu pada tubuh yang berguna untuk mengurangi bermacam-macam sakit dan nyeri serta mengaktifkan kembali peredaran energi vital dan chi. Hal ini sesuai dengan penelitian yang dilakukan di Taiwan tentang pengobatan nyeri punggung bawah dengan terapi akupresur dengan hasil bahwa terapi akupresur efektif dalam mengatasi nyeri punggung dan manfaatnya bertahan selama enam bulan (Issarata, 2013). Selama ini terapi akupresur dilakukan untuk mengurangi keluhan ibu hamil seperti mual muntah dan nyeri punggung selama proses persalinan. Selama ini ibu hamil menganggap bahwa keluhan nyeri punggung merupakan hal yang wajar terjadi selama kehamilan sehingga upaya yang dilakukan untuk mengurangi keluhan nyeri punggung bawah hanya istirahat saja (Kamariyah, 2014)

\section{METODE}

Penelitian ini merupakan penelitian kuantitatif dengan desain penelitian pre experiment yang bertujuan ingin mengetahui pengaruh teknik akupresur terhadap nyeri punggung bawah pada ibu hamil trimester III di wilayah kerja puskesmas Abiansemal 1 Kabupaten Badung.

Penelitian ini menggunakan pendekatan One group Pre post test design. Subjek pada penelitian ini adalah ibu hamil trimester III yang mengalami nyeri punggung bawah sebanyak 20 orang. Pada subjek penelitian sebelum dilakukan intervensi diukur skala nyeri (pre test) dengan menggunakan Visual Analog Scale (VAS). Kemudian setelah dilakukan pengukuran awal (pre test) subjek penelitian diberikan terapi akupresur selama 3 kali seminggu dalam 12 minggu Pada akhir penelitian dilakukan pengukuran kembali skala nyeri (post test) untuk mengetahui tingkat nyeri yang dirasakan oleh subjek penelitian setelah diberikan terapi akupresur. Penelitian ini dilakukan di tiga Bidan Praktik Mandiri (BPM) dan Puskesmas Abiansemal 1 pada bulan Februari-Juni 2018.

\section{HASIL}

\section{Gambaran Karakteristik Ibu Hamil TM III Dengan Nyeri Puggung Bawah di Wilayah Kerja Puskesmas Abiansemal I Kabupaten Badung}

Karakteristik pada subjek penelitian disajikan untuk mengetahui gambaran subjek penelitian. Pada penelitian ini karakteristik meliputi gravida, umur, pekerjaan dan pendidikan. 
Tabel 5.1 Karakteristik Ibu Hamil TM III Dengan Nyeri Puggung Bawah di Wilayah Kerja Puskesmas Abian Semal I

\begin{tabular}{lcc}
\hline \multicolumn{1}{c}{ Karakteristik } & $\mathbf{n}$ & $\boldsymbol{\%}$ \\
\hline Gravida & & \\
\hline Primigravida & 11 & 55,0 \\
\hline Multigravida & 9 & 45,0 \\
\hline Umur & 4 & 20,0 \\
\hline $20-25$ & 10 & 50,0 \\
\hline $26-30$ & 6 & 30,0 \\
\hline$>30$ & & \\
\hline Pekerjaan & 8 & 40,0 \\
\hline IRT & 7 & 35,0 \\
\hline Pedagang & 1 & 5,0 \\
\hline Buruh & 3 & 15,0 \\
\hline Swasta & 1 & 5,0 \\
\hline PNS & & \\
\hline Pendidikan & 0 & 0 \\
\hline Dasar & 12 & 60,0 \\
\hline Menengah & 8 & 40,0 \\
\hline Tinggi & & \\
\hline
\end{tabular}

Berdasarkan tabel.1 diinformasikan bahwa karakteristik responden. Sebagian besar responden adalah primigravida 11 orang $(55,0 \%)$, sedangkan sisanya 9 orang $(45 \%)$ multigravida. Sebagian besar responden berusia 26-30 tahun sebanyak 10 orang (50\%), kemudian umur 20-25 sebanyak 4 orang $(20 \%)$ sedangkan sisanya berusia > 30 tahun sebanyak 6 orang $(30 \%)$. Responden paling banyak sebagai Ibu Rumah Tangga 8 orang (40\%). Sebagian besar responden berpendidikan Menengah 12 orang (60\%), sedangkan sisanya berpendidikan tinggi 8 orang $(40,0 \%)$.

\section{Perbandingan Nyeri Punggung Bawah pada Ibu Hamil Trimester III Sebelum dan Sesudah Intervensi}

Tabel 2 Perbedaan Skala Nyeri Puggung Bawah Ibu Hamil Trimester III Sebelum dan Sesudah Intervensi di Wilayah Kerja Puskesmas Abiansemal I Kabupaten Badung.

\begin{tabular}{lccc}
\hline Skala Nyeri & Pre test & Post test & Nilai p \\
\hline Tidak nyeri & 0 & 14 & $0,001^{*}$ \\
\hline Nyeri ringan & 7 & 6 & \\
\hline Nyeri sedang & 13 & 0 & \\
\hline Nyeri berat & 0 & 0 & \\
\hline $\begin{array}{l}\text { Nyeri sangat } \\
\text { berat }\end{array}$ & 0 & 0 & \\
\hline
\end{tabular}

Keterangan uji *) Uji Wilcoxon

Pada tabel 2 dijelaskan perbandingan kategori nyeri sebelum penelitian terdapat 7 orang dengan skala nyeri ringan, 13 orang dengan skala nyeri sedang, setelah penelitian diperoleh 14 orang tidak nyeri dan 6 orang nyeri ringan. Hasil uji statitik dijelaskan bahwa terdapat penurunan yang signifikan kategori nyeri sebelum dan sesudah penelitian $(\rho<0,05)$. Berdasarkan hal tersebut menunjukkan bahwa terdapat pengaruh yang signifikan $(\rho<0,05)$ Terapi Akupresur Terhadap Nyeri Punggung Bawah Pada Ibu Hamil Trimester III Di Wilayah Kerja Puskesmas Abiansemal I Kabupaten Badung. 


\section{PEMBAHASAN}

Dari beberapa penelitian menyebutkan bahwa nyeri punggung ibu hamil tidak dipengaruhi oleh jumlah anak yang dimiliki sebelumnya, tingkat pendidikan atau umur ibu hamil karena salah satu penyebab nyeri punggung pada ibu hamil adanya peningkatan hormon estrogen dan progesteron yang menimbulkan perubahan pada jaringan lunak penyangga dan penghubung otot bagian belakang tubuh ibu sehingga menyebabkan menurunnya elastisitas dan fleksibiltas otot punggung (Johnson, 2014). Pada subjek penelitian, sebelum diberikan terapi akupresur, dilakukan pengukuran tingkat nyeri dengan metode visual analog scale (VAS). Terapi akupresur dilakukan 3 kali seminggu selama 12 minggu. Terapi akupresur dilakukan oleh therapist yang telah mengikuti pelatihan khusus akupresur. Terapi akupresur pada subjek penelitian diberikan sesuai dengan standart operating procedure akupresur supaya terapi yang diberikan pada semua responden pada seluruh subjek penelitian sama. Pada akhir penelitian yaitu minggu ke 12 dilakukan pengukuran tingkat nyeri post treatment dengan metode VAS. Dari hasil uji statistik terlihat bahwa terdapat perbedaan tingkat nyeri pada kelompok perlakuan sebelum dan sesudah penelitian. Terapi akupresur memberikan efek yang signifikan $(\mathrm{p}<0,05)$ terhadap penurunan nyeri punggung belakang pada ibu hamil. Akupresur merupakan salah satu teknik pengobatan tradisional dari cina yang digunakan untuk menurunkan nyeri. Akupresur adalah teknik yang memberikan tekanan fisik pada permukaan tubuh yang merupakan tempat sirkulasi energi dan keseimbangan pada kasus nyeri. Akupresur terbukti dapat mengurangi nyeri punggung, nyeri kepala dan mual muntah (Yurdanur,2012). Pada penelitian ini terapi akupresur dapat meringankan skala nyeri punggung bawah pada ibu hamil Trimester III. Nyeri punggung pada ibu hamil dapat terjadi pada akhir kehamilan, berdasarkan kajian yang dilakukan oleh Bullock et. Al (1987) bahwa sekitar 88,2\% ibu hamil mengalami nyeri punggung bawah dan terjadi pada usia kehamilan diatas 20 minggu (Sinclair,dkk,2014). Selain terjadinya perubahan postur pada ibu hamil, penyebab terjadinya nyeri punggung bawah pada ibu hamil adalah meregangnya ligamen penopang akibat perkembangan uterus sehingga menyebabkan terjadinya spasme pada daerah bagian bawah tulang belakang. Untuk mengurangi spasme pada ligamen ini maka diperlukan adanya penekanan pada titik-titik tertentu dengan teknik akupresur. Akupresur adalah teknik komplementer yang sederhana dan efektif dengan prinsip healing touch. Teknik akupresur menekan titik tubuh yang berhubungan dengan timbulnya rasa nyeri (Pravikasari,2014). Berdasarkan tabel 2 terdapat perbedaan skala nyeri punggung bawah pada ibu hamil trimester III sebelum dan sesudah perlakuan atau intervensi dengan hasil uji statistik $\mathrm{p}$ value $<0,05$. Hal ini karena dasar dari akupresur adalah menstimulasi saraf afferen tipe 1 dan tipe II atau serat A-delta di otot yang akan mengirim impuls menuju traktus anterolateral di medula spinalis. Sampai di medula spinalis nyeri dihambat pada presinaptik oleh pelepasan enchepalin dan dynorphin sehingga mencegah pesan nyeri sampai ke traktus spinothalamik.akupresur pada titik akupunktur akan memberikan efek lokal yaitu penurunan nyeri pada daerah sekitar titikm penekanan. Penekanan pada titik yang dilakukan akan memberikan efek perubahan biokimia, fisiologis dan persepsi atau rasa. Perubahan biokimia dapat berupa peningkatan kadar endorfin, perubahan fisiologis dapat berupa aktivitas aliran darah dan oksigen, sedangkan perubahan persepsi dapat berupa penurunan tingkat nyeri (Adikara, 2015).

Hasil penelitian ini sejalan dengan penelitian yang dilakukan di Taiwan terhadap $129 \mathrm{ibu}$ hamil yang mengalami nyeri punggung bawah yang diberikan terapi akupresur selama 20 menit dan dilakukan sebanyak 2 kali seminggu selama 4 minggu dapat menurunkan skala nyeri yang dirasakan oleh ibu hamil. Penelitian lainnya yang sejalan yaitu penelitian Pravikasari (2014) menjelaskan teknik akupresur dengan senam hamil lebih efektif menurunkan tingkat nyeri punggung bawah pada ibu hamil dengan $\mathrm{p}$ value $0,001(\mathrm{p}<0,05)$, setelah diberikan intervensi ibu hamil yang mengalami nyeri punggung bawah dengan skala tingkat nyeri dari sedang menjadi ringan sebanyak $13(86,7 \%)$ responden sedangkan $2(13,3 \%)$ mengalami nyeri sedang. Penelitian lainnya yaitu penelitian oleh Lisa Li Chen Hsieh,dkk (2006) dengan judul Treatment of low back pain by acupressure and physical therapy dengan metode Randomized Clinical Trial menyebutkan bahwa akupresur efektif mengobati nyeri punggung 


\section{SIMPULAN DAN SARAN}

Simpulan penelitian ini adalah terdapat pengaruh yang signifikan Terapi Akupresur Terhadap Nyeri Punggung Bawah Pada Ibu Hamil TM III di Wilayah Kerja Puskesmas Abiansemal $1(\rho<0,05)$. Disarankan kepada bidan-bidan untuk dapat memberikan pelayanan kebidanan secara komplementer melalui terapi akupresur untuk mengurangi nyeri punggung bawah pada ibu hamil Trimester III.

\section{DAFTAR PUSTAKA}

Adikara, R. T. S. (2015). Pelatihan Terapi Komplementer Alternatif \& Akupresur untuk Dokter, Perawat, Bidan dan Umum. Asosiasi Chiropractor dan Akupresur Seluruh Indonesia (ACASI) Cabang Bondowoso.

Association of Chartered Physiotherapists in Woman Health. (2011). Pregnancy Related Pelvic Girdle Pain Formerly Known As Symphysis Pubis Disfunction ACPWH.

Husin, F. (2014). Asuhan Kehamilan Berbasis Bukti. Bandung: Sagung Seto.

Issarata, Thanaporn, \& Lekskulchai, O. (2013). The Efficacy of Thai Massage in Relieving Low Back Pain among Pregnant Women in the Third Trimester. Journal of Thai Traditional \& Alternative Medicine. Vol. 11 No. 2.

Johnson, Traci, C. \& Faccog, M. (2014). Back Pain in Pregnancy. Web Md (http://www.webmd.com/baby/guide/back-pain-in-pregnancy dikutip pada 5 Maret 2017 Pkl 16.10 Wita.

Kamariyah, N., Anggasari, Y., \& Muflihah, S. (2014). Buku Ajar Kehamilan. Jakarta Selatan: Salemba Medika.

Katonis, P., Kampouroglou, A., Aggelopoulos, A. et al. (2011). Pregnancy Related Low Back Pain. Hippokratia, $15,3,205-210$.

Kementerian Kesehatan RI. (2014). Panduan Akupresur Mandiri bagi Pekerja di tempat Kerja. Jakarta: Kementerian Kesehatan RI.

Lisa Li Chen Hsieh, dkk. (2006). Treatment of low back pain by acupressure and physical therapy. BMJ Mander, Rosemery. Nyeri Persalinan. Jakarta: EGC. 2004.

Pravikasari. (2014). Perbedaan Senam Hamil dan Teknik Akupresur terhadap Penurunan Nyeri Punggung Bawah pada Ibu Hamil TM III. Semarang: Universitas Diponogoro.

Sinclair, Marlene. et al. (2014). How do Women Manage Pregnancy-Related Low Back and/or Pelvic Pain? Descriptive Findings from An Online Survey. Newabey: The Royal College of Midwives, 2014.

Stewart, Felshental, R. (2017). Pelvic Pain During Pregnancy. Meredith Corporation. 2011. (http://www.parents.com/pregnancy/mybody/achespains/pelvic-pain-pregnancy/dikutip pada 10 Maret 2017 Pkl.17.10 Wita.

Wang, Shu-Ming, M. D., Peggy Dezinno, R. N., B.S.N., Leona Fermo, C.R.N.A., William, K., Wong, \& Donna L. (2006). Maternity Child Nursing Care Third Edition. St. Louis Missouri: Mosby Elsevier.

Yurdanur, D. (2012). Non-Pharmacological Therapist in Pain Management-Current Issues and Opinions. Dr. Gabor Raez (Ed). 